Article

\title{
Entrepreneurship in an Increasingly Digital and Global World. Evaluating the Role of Digital Capabilities on International Entrepreneurial Intention
}

\author{
Laura von Arnim 1,*(D) and Matthias Mrozewski ${ }^{2}$ \\ 1 Department for Entrepreneurship and Innovation Management, Technical University of Berlin, \\ 10623 Berlin, Germany \\ 2 ESCP Business School Berlin, 14059 Berlin, Germany; mmrozewski@escp.eu \\ * Correspondence: laura.middermann@tu-berlin.de
}

Received: 4 September 2020; Accepted: 23 September 2020; Published: 26 September 2020

\begin{abstract}
Given the growing role of entrepreneurial companies in international markets, recent research endeavors direct their attention towards understanding the role of digital technologies for the internationalization efforts of new ventures. Thereby, existing research is mostly focused on explaining the enabling role of digital technologies as a contextual frame, but widely neglects the role of the individual and his/her capabilities to make use of those technologies. This paper aims at closing the above research gap by focusing on digital capabilities and investigating their effect on the intention to engage in international entrepreneurship. With the help of structural equation modeling, we integrate the concept of digital capabilities into the Theory of Planned Behavior (TPB) and empirically analyze the complex relationship between digital capabilities, the three TPB dimensions, and international entrepreneurial intention (IEI). Using a student sample from a major German university $(n=198)$, we find evidence for the significant role of digital capabilities for IEI through its positive effects on an individual's attitude towards international entrepreneurship and perceived behavioral control.
\end{abstract}

Keywords: digital capabilities; international entrepreneurship; entrepreneurship; theory of planned behavior; international entrepreneurial intention; Germany

\section{Introduction}

Recent entrepreneurship and innovation research agrees that digital technologies actas important "enablers" of entrepreneurial action [1,2]. The enabling effect can be mainly attributed to the circumstance that strategically important resources such as information and knowledge [3] are distributed more equally thanks to the wide availability of internet and cloud technologies [4], coming with free of charge information, communication and collaboration tools, and the necessary infrastructure [5]. Nowadays, potential customers can be reached easily through e-commerce sales channels, which allow for quick commercialization of newly developed products and services $[6,7]$. The evolution of the aforementioned technologies and tools is, moreover, significantly easing the spontaneous creative and collective processes needed for entrepreneurship and innovation activities (e.g., product development, etc.) by enhancing human collaboration without the need of physical presence [8]. As a consequence, venture projects can be set up quickly without requiring huge upfront investments, e.g., in office infrastructure. This all together significantly lowers the barriers of market entry for small entrepreneurial companies and enables them to successfully compete with incumbent firms. 
The positive effects of digitization for entrepreneurship are particularly visible in the international context as communication with international suppliers, customers, and business partners is increasingly accessible through the means of internet technologies and digital tools [9]. As a consequence, the high (and costly) risks typically associated with international business activity are significantly lowered which, in turn, creates an environment in which under-resourced firms can achieve quick internationalization $[10,11]$. It comes as no surprise that digitalization is seen as an important "enabler of international entrepreneurship" (IE) [12] (p. 661) as it facilitates resource-constrained new ventures and small firms to participate in international business activities [12-14]. Given the growing role of entrepreneurial companies in international markets [15], recent research endeavors direct their attention towards understanding the role of digital technologies for the internationalization efforts of new ventures [12-14,16,17].

The above research has its strengths, showing how digital technologies enable the internationalization of entrepreneurial firms, but widely neglects the role of the individual and his/her capabilities to make use of those technologies. This is problematic for two reasons. First and most importantly, the "enabling effect" of digital technologies can only be attained if individuals can make proper use of those technologies. Second, entrepreneurial firms are particularly influenced by the personality of the founder and are, therefore, increasingly driven by individual behavior and vision [18-20]. Thus, in an entrepreneurial context, it is mostly the individual decision maker who is an important antecedent of the firm's adoption of digital capabilities [21] and the discovery of international opportunities [22,23]. Consequently, without focusing on the capabilities and decision-making heuristics of the individual, the role of digital technologies for internationalization efforts can be understood only partly.

This paper aims at closing the above research gap by focusing on digital capabilities and investigating their effect on the very early stages of entrepreneurial internationalization, namely the intention of individuals to engage in IE (IEI). We are guided by the following research question:

\section{How Are Digital Capabilities Affecting IEI?}

Building on recent studies, which found that strategic decisions inherent in the internationalization process of entrepreneurial firms are determined by planned behaviors of individuals which are intentional by nature [23-25], we leverage on the theory of planned behavior (TPB) and build a framework explaining the role of digital capabilities for entrepreneurial action with an international focus. More precisely, we integrate digital capabilities into the TPB to explain IEI and empirically investigate the interactions between digital capabilities and the three dimensions of the TPB, namely attitude, subjective norm, and perceived behavioral control (PBC).

Our study contributes to research in two important ways. Firstly, it contributes to the literature on entrepreneurial decision-making by developing our theoretical understanding of the formation of entrepreneurial intentions driven by digital capabilities within the framework of the TPB. Through the integration of digital capabilities into individual-level theories of cognitive psychology and more precisely, by investigating the relationship between digital capabilities and the three cognitive variables of the TPB, we provide a theoretical framework for explaining the process of how digital capabilities affect IEI. Moreover, we empirically test this model and show that digital capabilities do indeed play a role in entrepreneurial decision-making by affecting attitude towards IE and PBC. By focusing on their individual level, we provide a differentiated view on the role of digital technologies in an entrepreneurial context [26]. Our approach is novel as individual-level research connecting digital technologies in the IE context is limited [27].

Secondly, we contribute to the IE literature by responding to the call of [12] (p. 674) for a better understanding on how "behaviors of founders impact the ability of their firms to pursue international opportunities in internet-enabled markets" [12] (p. 674). By empirically investigating the mechanisms within and linkages between digital capabilities, cognitive characteristics, and IEI, we advance the 
existing IE literature regarding digital technologies as a context factor $[28,29]$ or firm resource $[9,30]$ by a cognitive perspective on the role of digital technologies in IE.

Finally, our research is important from a sustainability point of view as developing countries are particularly profiting from the business opportunities associated with IE. While traditional global industries are characterized by a domination of large western multinational companies, the global entrepreneurship landscape is widely different. Thus, approx. $50 \%$ of so called unicorn startups (new technology based firms valued at $>$ USD 1 bn) can be classified as stemming from non-western countries (such as China, India, Ukraine, etc.), which is a sign that firms from less-developed economies are increasingly taking those chances and as a consequence, foster regional economic growth.

\section{Background Literature and Theory}

\subsection{TPB and IEI}

"Intentions are assumed to capture the motivational factors that influence a behavior" [31] (p. 181) and are the construct of use when it comes to the investigation of decision making [32]. According to the TPB, intention can be described as the willingness to achieve a given behavior [33] and is mainly influenced by three determinants. The first is attitude towards the behavior, which is explained as the "degree to which a person has a favorable or unfavorable evaluation of the behavior in question" [32] (p. 454). The second determinant described in the theory is subjective norm, which captures the social pressure to achieve the behavior [31,32]. The third factor influencing intention is PBC, which is seen as the perceived ease of accomplishing the behavior under evaluation of the perceived abilities, resources, and opportunities [31]. PBC is closely related to Bandura's concept of perceived self-efficacy [34] and conceptualized by the confidence in the ability to perform the behavior and in controllability [35].

Consistent with previous studies, the three dimensions-attitude towards the behavior, subjective norm, and $\mathrm{PBC}$ - are taken to drive entrepreneurial intentions [36,37] and pose that this relationship is also valid when considering IEI $[23,38,39]$.

IEI, described as the willingness to actively exploit business opportunities abroad "in the race for new markets" [39] (p. 294), has been found to be an important predictor for entrepreneurial growth and performance [16]. Specifically, in an increasingly globalized and digitalized world, "internationalization is not just an option that firms can choose to follow, but has become an important precondition for economic success" [40] (p. 1014), with expected higher outcomes the earlier an entrepreneurial firm engages in and commits to foreign markets. Thus, the analysis of the drivers of IE is a key topic in IE research $[40,41]$.

Based on the field of general entrepreneurship, the individual entrepreneur is seen as the key decision-maker of strategic decisions [42], such as the decision to engage in IE [15]. This highlights the role of the individual for the identification and exploitation of international entrepreneurial opportunities [23] and it is sensible to understand "how entrepreneurs think and make decisions" [43] (p. 135) to explain why some intend to engage in IE while others do not.

Thus, previous studies revealed several behavioral factors that play an important role in the formation of IEI. In this vein, various studies have emphasized the importance of the three behavioral determinants-innovativeness, proactiveness and risk-taking-in shaping an international entrepreneurial orientation (for a review, see [44]). Additionally, a considerable number of studies have highlighted a global mindset, represented by an openness for and understanding of different national contexts and cultures [45-47], as well as a positive attitude towards IE [22,38,39], as important factors and drivers of IEI.

\subsection{Digital Capabilities and IEI}

Combining the above discussion with the arguments that the internationalization of entrepreneurial firms is attributed to the decision maker's cognitive and behavioral antecedents $[43,48]$ and that the decision maker is an important antecedent of the firm's adoption of digital capabilities [12], we argue 
that individual-level digital capabilities are important for entrepreneurial internationalization decisions. Individual capabilities encompass the ability to combine unique resources such as human capital, to achieve greater firm performance and competitive advantage [26,49]. A variety of individual-related digital capabilities such as technical, behavioral, physical, managerial, and relational have already been subject to prior research [26], but rarely in the context of IE.

We describe digital capabilities as the decision maker's "cognitive potential to make proper use of ICTs" [50] (p. 50) for business purposes [51]. Thus, with the use of digital technologies, individuals can gain important knowledge about foreign markets [52] through easy and efficient access to foreign market data [53]. Furthermore, it allows them to communicate across borders with potential customers [21] and suppliers [54,55], thus building relevant networks [56]. This enhances the efficiency of entrepreneurial decision making and the evaluation of markets and customers [57], and allows for identifying promising business ideas [58]. Glavas and Mathews [21] found that international entrepreneurs who internationalized proactively own an elevated level of digital capabilities. They argue that "these international entrepreneurs were seeking to identify and exploit new opportunities through the adoption of internet capabilities" [21] (p. 242).

Based on this discussion, it is reasonable to assume that individuals coming with superior digital capabilities are advanced when engaging in international entrepreneurial activity. However, only individuals who are able to use the above tools effectively are expected to profit from the advantages they provide for international business activity.

\section{Conceptual Framework and Hypothesis Development}

\subsection{Digital Capabilities, Attitude towards the Behavior, and IEI}

Previous research already confirmed the influence of attitudinal elements of TPB on entrepreneurial intention in general $[37,59]$ and specifically, in the international context $[38,39]$. In line with that, we expect digital capabilities to influence IEI through their positive impact on attitude towards IE.

Attitude towards behavior is explained as the "degree to which a person has a favorable or unfavorable evaluation of the behavior in question" [32] (p.454). The behavior in question in our context is IE, which is defined by Oviatt and McDougall [60] (p. 540) as the "discovery, enactment, evaluation, and exploitation of opportunities-across national borders- to create future goods and services". The evaluation of whether an idea is also a real opportunity which is worth considering is dependent on the risk perception of the entrepreneur [61,62]. Previous research has shown that risk perception is an important determinant of the attitude towards IE [39]. Thus, it may be expected that the fewer information an individual has about the feasibility of an opportunity, the higher the perceived uncertainty and the less favorable the evaluation of the opportunity $[61,62]$. Thus, without having access to relevant information, an opportunity seems to be less attractive. This mechanism is particularly strong in an international context, as cross-border trade and investment involve more uncertainty and risk than local business, and are typically confronted with a lack of information [21]. Given that digital capabilities help to overcome those information asymmetries by allowing access to information on foreign markets, the perceived risk of internationalization is reduced [63]. With a reduced risk, opportunity feasibility increases and as a consequence, also the attitude towards acting upon this opportunity grows.

Hence, we expect that digital capabilities increase information availability and market knowledge and hence, lead to a favorable evaluation of IE. We, therefore, hypothesize that digital capabilities are indirectly and positively related to IEI by affecting the attitude towards IE. We hypothesize:

Hypothesis 1a (H1a). Digital capabilities positively influence the attitude towards IE.

Hypothesis $\mathbf{1 b} \mathbf{( H 1 b ) . ~ T h e ~ a t t i t u d e ~ t o w a r d s ~ I E ~ h a s ~ a ~ p o s i t i v e ~ i m p a c t ~ o n ~ I E I . ~}$ 


\subsection{Digital Capabilities, Subjective Norm, and IEI}

Conceptually closely related to the theory of normative conduct [64], a subjective norm refers to a person's perception that important people belonging to a person's surrounding favor the behavior in question [65]. Thus, the more positive the evaluation of a certain behavior by an individual's social environment, the more he or she will intend to do so [32,66].

Despite most findings of previous empirical research reporting a positive role of subjective norm for entrepreneurial intention in a general context $[36,67,68]$, the role of the subjective norm for IEI is less clear and previous studies [25,38,39] could not find a positive link between subjective norm and IEI. These contrary findings accompany the note of Ajzen [31] that the predictive strength of the dimensions can vary across situations.

However, as it is known that other people can influence individual behavior because of their ability to mediate behavioral outcomes [69], we assume that IE behavior may also be affected by normative influences. Furthermore, and in line with Zapkau et al. [68], we argue that the people referred to are often well informed about the human capital of an individual and formulate opinions and recommendations based on the information they possess about those capabilities. It may be expected that they will particularly encourage actions which are related to the capabilities of the individual as they are realistic and therefore, will likely bring about desired outcomes [68]. At the same time, they will discourage the individual to take actions which are not related to his/her set of capabilities, as this increases the likelihood of undesired outcomes, such as failure.

Thus, it may be expected that the social environment will play an important role for an individual's decision of founding and running a business with all its consequences [70]. Thereby, his or her capabilities may play an important role in shaping the beliefs of the social environment as to the desirability of this behavior. Indeed, a subjective norm is strictly related to an individual's social environment, but it can be affected by the skills of the individual. Thus, family members and close friends are often well informed about the skills and capabilities of an individual and formulate opinions and recommendations based on the information they possess about those capabilities. It might be expected that they will particularly encourage actions which are related to the skills of the individual as they are realistic and hence, will likely bring about desired outcomes. At the same time, they will discourage the individual to take actions which are not related to their skill set as this increases the likelihood of undesired outcomes, such as failure. Thus, if they know that an individual has shown superior digital capabilities in the past, they might be more likely to believe that the individual will be able to use those skills to successfully compete internationally. Hence:

Hypothesis 2a (H2a). Digital capabilities positively influence subjective norm.

Hypothesis $\mathbf{2 b} \mathbf{( H 2 b ) . ~ S u b j e c t i v e ~ n o r m ~ h a s ~ a ~ p o s i t i v e ~ i m p a c t ~ o n ~ I E I . ~}$

\subsection{Digital Capabilities, PBC, and IEI}

The third factor influencing intention is $\mathrm{PBC}$, which is seen as the perceived ease of accomplishing the behavior under evaluation of the perceived abilities, resources, and opportunities [35]. PBC is found to be a strong predictor of entrepreneurial intentions in general [36] and specifically in the international context [39].

Thereby, it is likely that PBC is increasing if an individual's level of digital capabilities is growing. With enhanced digital capabilities, individual actors can access different internet-based information channels to acquire information which are hidden to individuals with fewer digital capabilities [26]. Based on that information, they can effectively assess whether their abilities are sufficient to survive in international markets, which resources are available internationally, and which market segments bring about the highest profitability. Based on this information, individuals can better plan potential activities, quantify potential risks, and apply risk management techniques accordingly [71,72]. This again increases the belief that accomplishing IE behavior is realistic and that one is prepared for different scenarios 
and therefore, can effectively control the internationalization process. Furthermore, in a business surrounding which is increasingly based on digital solutions [1,73], digital capabilities should transform into higher self-confidence of an individual. Thus, it is hypothesized:

Hypothesis 3a (H3a). Digital capabilities positively influence the PBC.

Hypothesis $\mathbf{3 b} \mathbf{b} \mathbf{H} 3 \mathbf{b})$. PBC has a positive impact on IEI.

Combining the abovementioned arguments, this study argues that the effect of digital capabilities on IEI is indirect as it is mediated by the three attitudinal variables of the TPB-namely attitude towards IE, subjective norm, and PBC. Figure 1 shows our research model.

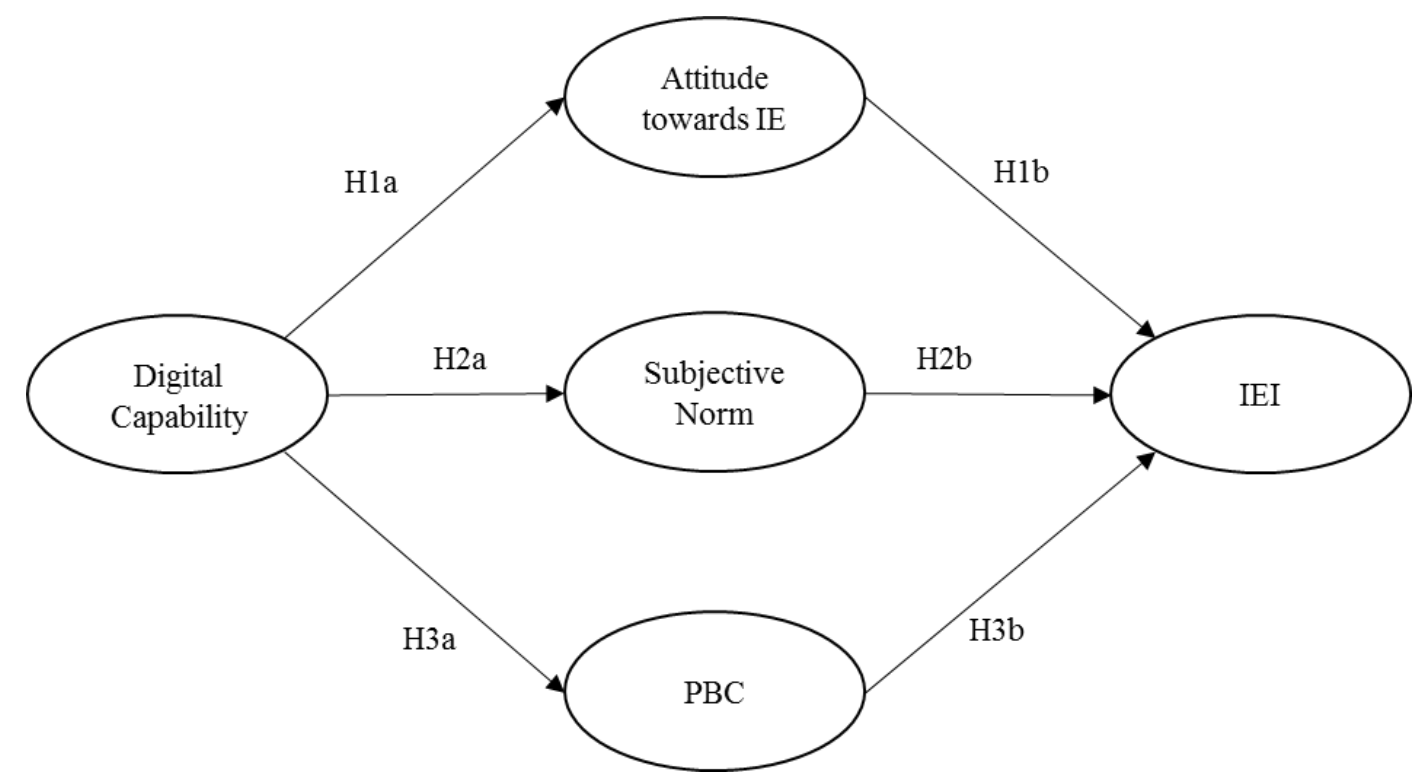

Figure 1. Research Model to explain the Influence of Digital Capabilities on IEI: Own model approach with elements from TPB (Ajzen, 1991).

\section{Methodology}

\subsection{Data}

To test our conceptual model, we collected data from 198 students who took entrepreneurship courses at a major German university. We focused on this sample for two reasons. First, the TPB has been developed on students [32] and entrepreneurial intentions have mainly been tested on students $[37,59,68,74-83]$. In addition, in our case, entrepreneurship students seem to be an appropriate sample due to two reasons. Firstly, regarding the antecedents of entrepreneurship, students appear to be an appropriate sample, as individuals with entrepreneurship education are more likely to engage in entrepreneurship $[81,84]$. Secondly, as IEI is preceding IE, to isolate intention from opportunity exploitation, it is necessary to survey individuals who are not engaged in starting up a business yet.

We used a questionnaire to gain self-reported data, as we focused on intention measures which are self-reported by definition [36]. However, we are confident that the self-reported information collected is robust as it does not contain any sensitive information which might lead to biased results [67].

Overall, we asked 335 entrepreneurship students to take part in our survey and received 261 responses. After excluding cases with missing data, our sample consists of 198 self-reported measures. Female participants made up 44 percent of the sample. The average age was 25 years $(\mathrm{SD}=$ $2.7 ; \min =20 ; \max =35$ ). 


\subsection{Measures}

To measure the dependent variable IEI, we took scales proposed by (Kautonen, van Gelderen, and Fink 2015) [36] and adapted them to the international context. Thus, to measure the dependent variable, we replaced "to start a business in the next 12 months" with "to start an internationally operating business in the future". Overall IEI was measured with three items of a participant's perception about taking steps to start an internationally operating business in the future.

Similarly, we used scales from Kautonen, van Gelderen, and Fink (2015) [36] to measure the three mediating variables - namely, attitude towards the behavior, subjective norm, and PBC—suggested by the TPB. Attitude towards the behavior covers the participants' evaluation about taking steps to start an internationally operating business and was measured by six items. In line with previous research recommending direct measures [31,77], subjective norm was recorded with three items of normative beliefs that cover an individual's perception of the pressure which family members, best friends, and other important people exert with respect to the decision of taking steps to start an internationally operating business [39].

PBC comprises the individual's perception of the degree to which they are able and have the control over taking steps to start an internationally operating business in the future [38]. PBC was measured with four items proposed by Kautonen, van Gelderen, and Fink (2015) [36]. All items were ranked on a six-point Likert scale, ranging from $1=$ strongly disagree to $6=$ strongly agree.

For digital capabilities, we applied the measurement of firm-level capabilities used by Parida and Örtqvist (2015) [51] and adjusted the questions to the individual level by applying the approach of Mullins and Sabherwal 2014 [85] of using a stimulus. Hence, we introduced our scales with the situation that a new software would be available to support international activity. Hereby it does not matter what specifically the software does [85], simply that there is a new software available to support international activity. To capture digital capabilities specified as the readiness to use a new software, the participant had to evaluate the extent to which he or she would rely on the new software besides using other resources. Overall, we use nine items to measure our independent variable of digital capabilities. All digital capabilities items were measured analogue to the TPB constructs-by the means of six-point Likert scales ranging from $1=$ strongly disagree to $6=$ strongly agree. Appendix A lists the items and stimuli used to create the measures of this study.

\subsection{Structural Equation Modeling}

Means, standard deviations, and correlations of the variables are provided in Table 1.

Table 1. Correlations and descriptive statistics of measurement variables.

\begin{tabular}{|c|c|c|c|c|c|c|c|c|}
\hline & & Mean & SD & (1) & (2) & (3) & (4) & (5) \\
\hline (1) & IEI & 3.87 & 1.43 & 1.00 & & & & \\
\hline (2) & $\begin{array}{l}\text { Attitude towards } \\
\text { IE }\end{array}$ & 4.61 & 0.98 & $0.59^{* * *}$ & 1.00 & & & \\
\hline (3) & Subjective Norm & 3.64 & 1.30 & $0.58^{* * *}$ & $0.48^{* * *}$ & 1.00 & & \\
\hline (4) & PBC & 3.75 & 0.91 & $0.42^{* * *}$ & $0.25^{* *}$ & $0.50 * * *$ & 1.00 & \\
\hline (5) & $\begin{array}{c}\text { Digital } \\
\text { Capabilities }\end{array}$ & 4.16 & 0.92 & $0.26^{* *}$ & $0.26^{* *}$ & 0.10 & $0.28 * *$ & 1.00 \\
\hline
\end{tabular}

Note: $n=198$, correlations are significant at $p<0.001^{* * *}$ and $p<0.01^{* *}$.

All the correlations of the variables are below 0.7 and the variation inflation factors are below the value of 1 , with a tolerance greater 0.1 indicating that multicollinearity is not problematic [86-88].

Digital capabilities correlate significantly with IEI $(r=0.26 ; p<0.001)$, which indicates that there is a positive relationship between an individual's digital capabilities and his or her intention to become an internationally active entrepreneur. Similarly, the three TPB dimensions are significantly and positively related to IEI (Attitude: $r=0.59, p<0.001$; subjective norm: $r=0.58, p<0.001$; PBC: $r=0.42, p<0.001$. 
Another important insight from correlation analysis is the fact that digital capabilities and PBC correlate relatively weakly $(r=0.28 p<0.01)$. This shows that from a statistical point of view, they are distinct concepts (Theoretically, it might be questioned whether PBC and digital capabilities are distinct concepts as PBC encompasses, among others, the evaluation of the perceived abilities to accomplish a certain behavior, while digital capabilities mirror the perceived ability to deal with digital technologies. However, at this point, it is worth noting that in our research context, the behavior in question is not founding an IT-based business but founding an internationally operating venture. Hence, PBC in our research context is related to the evaluation of the ability to run an international business and is, therefore, theoretically distinct from digital capabilities, which is also proven by the results of the correlation analysis).

Our research hypotheses require the testing of whether attitude towards IE, subjective norm, and PBC mediate the impact of digital capabilities on IEI.

Following frequent recommendations that structural equation modeling (SEM) is a superior approach for testing mediation effects [89,90], compared to traditional approaches like Baron and Kenny 1986 [91], we apply SEM to test our proposed hypotheses (However, due to the small sample size and for robustness purposes, we additionally conducted the traditional Baron and Kenny method [91] and a Preacher and Hayes bootstrapping approach [92] to check if the results remain stable). Therefore, we operationalize our measured items into reflective variables, which help us to control for measurement error [93].

Before estimating the SEM, we checked the robustness of our measurement construct. To check common method variance, we conducted Harman's single factor test [94]. Hence, five variables were extracted in one factor with an eigenvalue greater than one. Common method bias is suggested if one factor contributes to more than 50 percent of the total variance [94]. Our extracted factor explained 29.34 percent of the total variance and confirms that one factor did not account for the majority of the variance. Our exploratory factor analysis indicates that all items load on their theoretically assigned factors (Table 2); therefore, we proceeded with a confirmatory factor analysis (CFA). The results of the CFA and Cronbach's alpha are provided in Table 3.

Table 2. Results of exploratory factor analysis.

\begin{tabular}{|c|c|c|c|c|c|}
\hline & $\begin{array}{c}\text { Digital } \\
\text { Capabilities }\end{array}$ & $\begin{array}{c}\text { Attitude } \\
\text { towards IE }\end{array}$ & IEI & $\begin{array}{c}\text { Subjective } \\
\text { Norm }\end{array}$ & PBC \\
\hline Item 1 & 0.052 & 0.287 & 0.748 & 0.262 & 0.205 \\
\hline Item 2 & 0.143 & 0.248 & 0.851 & 0.262 & 0.123 \\
\hline Item 3 & 0.137 & 0.278 & 0.795 & 0.233 & 0.125 \\
\hline Item 4 & 0.100 & 0.594 & 0.495 & 0.100 & -0.022 \\
\hline Item 5 & 0.094 & 0.724 & 0.242 & 0.155 & 0.115 \\
\hline Item 6 & 0.016 & 0.776 & -0.042 & 0.118 & 0.201 \\
\hline Item 7 & 0.097 & 0.849 & 0.247 & 0.009 & 0.030 \\
\hline Item 8 & 0.124 & 0.758 & 0.140 & 0.206 & 0.051 \\
\hline Item 9 & 0.129 & 0.712 & 0.129 & 0.159 & -0.100 \\
\hline Item 10 & -0.021 & 0.217 & 0.119 & 0.823 & 0.196 \\
\hline Item 11 & -0.012 & 0.231 & 0.315 & 0.760 & 0.165 \\
\hline Item 12 & 0.027 & 0.243 & 0.282 & 0.827 & 0.098 \\
\hline Item 13 & 0.220 & -0.003 & 0.124 & 0.366 & 0.474 \\
\hline Item 14 & 0.074 & 0.129 & 0.014 & 0.298 & 0.690 \\
\hline Item 15 & 0.138 & 0.010 & 0.106 & 0.285 & 0.766 \\
\hline Item 16 & 0.004 & 0.075 & 0.145 & -0.171 & 0.764 \\
\hline Item 17 & 0.762 & 0.006 & -0.055 & 0.098 & 0.051 \\
\hline Item 18 & 0.754 & 0.062 & -0.032 & 0.106 & 0.073 \\
\hline Item 19 & 0.754 & 0.154 & -0.219 & 0.048 & 0.099 \\
\hline Item 20 & 0.672 & 0.081 & 0.035 & 0.024 & 0.014 \\
\hline Item 21 & 0.722 & 0.058 & 0.091 & 0.022 & 0.048 \\
\hline Item 22 & 0.743 & -0.046 & 0.290 & -0.051 & 0.039 \\
\hline Item 23 & 0.746 & 0.070 & 0.093 & 0.031 & 0.067 \\
\hline Item 24 & 0.738 & 0.050 & 0.145 & -0.059 & 0.113 \\
\hline Item 25 & 0.751 & 0.187 & 0.150 & -0.085 & -0.045 \\
\hline
\end{tabular}

Note: Principal component analysis with varimax rotation and Kaiser normalization. 
Table 3. Results of the confirmatory factor analysis.

\begin{tabular}{|c|c|c|c|c|c|}
\hline Construct & Item & Mean & SD & $\begin{array}{c}\text { Standardized Factor } \\
\text { Loadings }\end{array}$ & $\begin{array}{c}\text { Cronbach's } \\
\text { Alpha }\end{array}$ \\
\hline \multirow{4}{*}{ IEI } & Item 1 & 3.70 & 1.583 & 0.827 & \multirow[t]{4}{*}{0.91} \\
\hline & Item 2 & 3.91 & 1.495 & 0.965 & \\
\hline & Item 3 & 3.98 & 1.572 & 0.876 & \\
\hline & Item 4 & 4.65 & 1.293 & 0.708 & \\
\hline \multirow{5}{*}{ Attitude towards IE } & Item 5 & 4.75 & 1.219 & 0.733 & \multirow[t]{5}{*}{0.87} \\
\hline & Item 6 & 4.39 & 1.199 & 0.661 & \\
\hline & Item 7 & 4.70 & 1.191 & 0.848 & \\
\hline & Item 8 & 4.40 & 1.286 & 0.763 & \\
\hline & Item 9 & 4.74 & 1.295 & 0.696 & \\
\hline \multirow{3}{*}{ Subjective Norm } & Item 10 & 3.39 & 1.452 & 0.768 & \multirow[t]{3}{*}{0.89} \\
\hline & Item 11 & 3.80 & 1.471 & 0.887 & \\
\hline & Item 12 & 3.73 & 1.380 & 0.927 & \\
\hline \multirow{4}{*}{ PBC } & Item 13 & 4.57 & 1.176 & 0.583 & \multirow[t]{4}{*}{0.70} \\
\hline & Item 14 & 4.08 & 1.150 & 0.661 & \\
\hline & Item 15 & 3.18 & 1.304 & 0.782 & \\
\hline & Item 16 & 3.19 & 1.344 & 0.460 & \\
\hline \multirow{9}{*}{ Digital Capabilities } & Item 17 & 4.24 & 1.167 & 0.713 & \multirow{9}{*}{0.90} \\
\hline & Item 18 & 3.94 & 1.150 & 0.71 & \\
\hline & Item 19 & 4.23 & 1.155 & 0.708 & \\
\hline & Item 20 & 3.86 & 1.203 & 0.629 & \\
\hline & Item 21 & 4.02 & 1.264 & 0.692 & \\
\hline & Item 22 & 4.45 & 1.256 & 0.728 & \\
\hline & Item 23 & 4.36 & 1.329 & 0.727 & \\
\hline & Item 24 & 3.98 & 1.290 & 0.722 & \\
\hline & Item 25 & 4.32 & 1.285 & 0.742 & \\
\hline
\end{tabular}

All items load significantly on their variable and the standardized factor loadings of the CFA are above 0.66 , except for one item of the PBC variable, which shows a loading of 0.46 . Furthermore, the reliability of variables is satisfying, as Cronbach's alpha reaches 0.7 at minimum [86]. Taking the results into account, our measurements' construct shows a good internal consistency.

Following Williams, Vandenberg, and Edwards (2009) [93] and Iacobucci (2010) [95], we assess the model fit of the measurements by applying widely used fit indices of Chi-square $\chi^{2}$, standardized root mean square residual (SRMR), the comparative fit index (CFI), and the root mean square error approximation (RMSEA) as recommended fit indices. As our $\chi^{2}$ adjusted by its $d f$ does not exceed a recommended minimum of 3.0 [95], our SRMR is below the recommended threshold of 0.08 , our CFI is close to 0.95 [96], and our RMSEA is lower than 0.08 [94], we suggest an acceptable measurement fit of our model $\left(\chi^{2}=556.4 / d f=265 \leq 3\right.$, SRMR $=0.06$; CFI $=0.89$; RMSEA $\left.=0.0075\right)$.

\section{Results}

After having achieved a good fit in the measurement model, we added the structural path. The results of our structural model also indicate an acceptable fit $\left(\chi^{2}=558.48 / d f=266 \leq 3\right.$, SRMR $=$ 0.0056; $\mathrm{CFI}=0.89$; RMSEA $=0.0075)$. Figure 2 displays the results. 


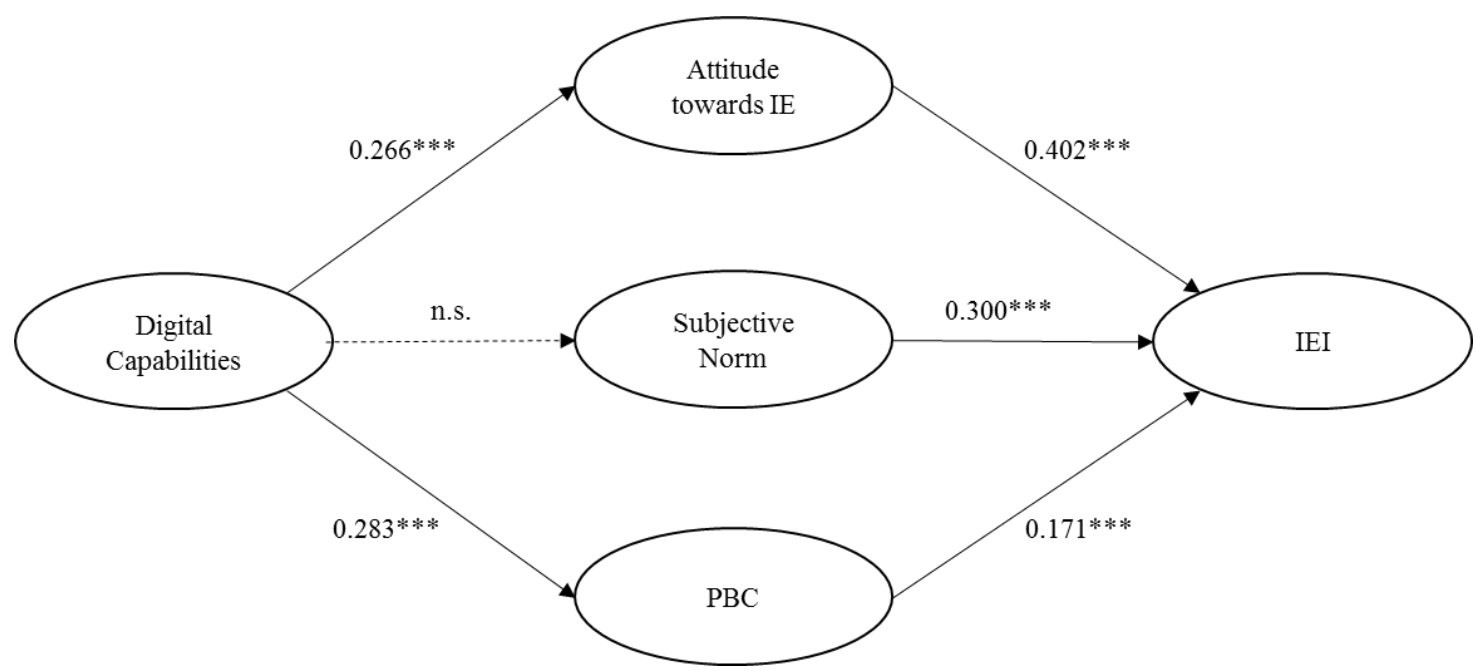

Figure 2. Note: ${ }^{* * *} p<0.001 ;$ n.s. $=$ non-significant.

The standardized regression weights show that all attitudinal variables of the TPB display a significant and positive effect (attitude: $0.40, p<0.001$; subjective norm: $0.30, p<0.001$; PBC: $0.17, p<0.01$ ) on the outcome variable IEI, which confirms Hypotheses H1b, H2b, and H3b. Furthermore, the capture of digital capabilities positively and highly significantly $(p<0.001)$ influences the attitude towards IE (0.27) and PBC (0.28), which confirms Hypothesis H1a and Hypothesis H3a. However, we could not find a significant effect of digital capabilities on subjective norm, which rejects Hypothesis H2a.

\section{Discussion}

Applying the TPB as intention-based, we argue that the link between digital capabilities and IEI is complex and that cognitive dimensions play an important role in explaining this relationship. In accordance with prior studies $[23,38,39]$, we found empirical support for the application of the TPB to explain IEI. This provides empirical support for the crucial role of attitude, subjective norm, and PBC for the development of entrepreneurial intentions at an international level. This adds to the growing stream of entrepreneurship research leveraging on TPB to explain entrepreneurial activity $[36,37,70]$ and provide empirical evidence that the predictions of TPB also hold when the international context is considered [23,39]. Furthermore, this strengthens the growing body that argues for a cognitive and individual level of the entrepreneur to investigate the formation of IEI [25,43].

Furthermore, we found empirical evidence for the role of digital capabilities for IEI in general. Thus, we find that digital capabilities are a significant predictor of IEI, which extends findings of previous research that already highlight the role of demographic characteristics as e.g., migration background [22], institutional environments [97], attitudinal elements like international entrepreneurial orientation and a global mindset [44,97], as well as human capital and experiences [40] for IE.

More precisely, our empirical results show that two of the three dimensions of the TPB-namely, attitude towards the behavior and PBC - mediate the influence of digital capabilities on IEI. This finding confirms previous studies $[67,68]$ that exogen influences—such as digital capabilities—on IEI are mediated by the TPB.

Hence, digital capabilities positively influence the attitude towards IE. This can be explained by the fact that digital capabilities provide individuals with superior access to international information, hence reducing uncertainty related to international activities and allowing for a more effective identification of promising international opportunities [72].

Furthermore, we have shown that digital capabilities positively affect PBC, which is seen as the perceived ease of accomplishing the behavior under evaluation of controllability and self-efficacy [35]. Thus, we assume that individuals coming with superior digital skills are more self-confident to survive in the international context, which can be explained by better market information as well as efficient 
use of online channels for communication, collaboration, and sales [13,98]. This perception translates into an increased self-efficacy which, in turn, increases IEI [39]. Therefore, it may be assumed that digital capabilities give individuals the impression of being able to effectively control and handle the complicated process of internationalization.

In line with our expectations but contrary to previous research (for example [25,38,39]), we indeed could find a positive effect of subjective norm on IEI, though we did not find a positive effect of digital capability on subjective norm. Hence, our hypothesis that digital capabilities are impacting IEI through subjective norm must be neglected. This finding may be explained by the fact that in contrast to attitude and $\mathrm{PBC}$, subjective norm is not strictly related to the individual and his/her psychological characteristics but is rather shaped by the social environment. Bearing in mind that the likelihood of normative social influence depends on the visibility of the behavior to the social surrounding [69], it may be assumed that digital capabilities, however, are individual-specific and other people do not have full information on this aspect. Therefore, digital capabilities have an influence on the individual's attitude and PBC, but not on the way his/her social environment perceives the abilities of an individual and how he or she is fulfilling the expectations of affiliated persons.

Our findings can be interpreted as a first indication that cognitive dimensions are influenced by information availability and by the use of digital technologies. As we have shown, digital capabilities help individuals to build their IEI by increasing attitudes toward IE and PBC and hence, encourage them to engage in IE. Consequently, international markets are not anymore reserved for the resource-endowed but are increasingly open to individuals with superior digital capabilities. This notion becomes apparent when reflecting that the most successful international companies such as Amazon, Facebook, or Google were not founded by experienced managers but by (former) IT students. Taking into account that the importance of digital technologies in international business and entrepreneurship is growing, it might be expected that the interplay between digital capabilities and cognitive dimensions will be responsible for the appearance of further international new ventures in the future.

\section{Conclusions}

This study investigates the effect of digital capabilities on IEI to gain a better knowledge on how digital capabilities affect the decision of becoming an international entrepreneur in the future. Herewith, we extend the current IE literature by proving a cognitive perspective on the link between digital capabilities and IE.

Our results show that attitude towards IE, and PBC in regard to IEI are better predictors of IE compared to the direct effects of digital capabilities. Thereby, we confirm previous research stating that the link between digital capabilities and its outcome is complex and cannot be fully explained by direct effects [26,49]. Additionally, we provide insights about the role of digital capabilities besides being a firm resource [26] and thus, contribute to recent calls for a better understanding of how digital capabilities advance cognitive entrepreneurial characteristics on the individual level that favor IE $[12,27]$.

Second, we advance IE research and more specifically, the literature on IEI (for example, [22,23,25,38,39]) by underlining the effect of individual-level factors, including digital capabilities in internationalization decisions. Thus, using the TPB, we explain the mechanism leading to the formulation of the intention to create an internationally operating business and empirically show that digital capabilities play a major role here by positively affecting the attitude towards IE and PBC, which are important determinants of IEI. Taking into account that in entrepreneurial firms, strategic decisions such as internationalization are driven by individuals, we hence provide an answer to the question of how IEI are formed.

Our results are important from a practice perspective as they show that digital capabilities should not be reduced to the role of helpful tools facilitating operative day-to-day tasks but should be regarded as strategically important determinants of entrepreneurial decision-making [49]. Hence fostering digital capabilities results not only in a higher supply of IT experts needed in today's digitally shaped 
world, but also increases the likelihood of the appearance of a new Apple, Facebook, or Google. This should also be considered by venture capitalists who are usually interested in a rapid growth of the startup they invest in. Hence, to assess the scalability and growth potential of a new venture, it is not enough to consider the idea itself and the market prospects but increasingly focus on the digital capabilities of the founding team to assess their intentions, motivation, and hence, international growth perspectives. We furthermore show that entrepreneurship can be fostered not only through entrepreneurship-specific measures but also through the enhancement of digital capabilities. This has not only implications for entrepreneurship practitioners but also for managers aiming at fostering corporate entrepreneurship. Furthermore, our findings also have implications for managers when they are interested in strengthening entrepreneurial attitudes and global orientation of their employees, whereas it could be shown that increasing digital capabilities can be regarded as an effective way to do this. Thus, digital technologies open "internal boundaries and hierarchical barriers" [28] (p. 224) within a firm, which results in easy access to important information and knowledge about foreign markets.

Finally, our findings have implications for public decision makers. We have shown that digital capabilities should no longer be regarded only as a resource for firm advantage but also for shaping IEI and thus, helping individuals to internationalize their entrepreneurial firms. Thus, whenever IE is a desired outcome of public policy, the portfolio of instruments should include measures that foster digital capabilities. We conclude that traditional internationalization support like institutional support should be extended by IT education, which helps individuals to efficiently evaluate IE outcomes and positively affect their resources, abilities, and consequently, PBC to engage in IE.

\section{Limitations and Future Research}

As with every study, our research is confronted with potential limitations. Firstly, as intention is self-reported by definition [36], our dataset also comes with the threat of a response bias. Respondents could overestimate their cognitive characteristics such as PBC. However, having in mind that the bias is mostly related to the query of sensitive data [67], we are confident that our results are not biased. Secondly, we focused on the earlier stage of TPB and neglected the relationship between intention and actual behavior. However, using theoretical arguments of TPB stating intention as a predictor of behavior [33] and empirical findings in a general entrepreneurial context [36,37], we are convinced that our results are relevant for international entrepreneurial behavior as well. Nevertheless, future research could extend our findings and concentrate on the later stages of the TPB by empirically showing that the intention-behavior link is also valid in the IE context. According to Zapkau et al. (2015) [68] and Davidsson and Honig (2003) [99], we postulate that longitudinal studies of our investigation would allow for direct observation of if the independent variables influence intention and at a later stage, behavior as well-more specifically, if the individuals coming with superior digital capabilities are subsequently also more often engaged in international entrepreneurial activity than their fellows coming with lower levels of digital capabilities. Thirdly, our sample consists of students enrolled in an entrepreneurship course, which on the one hand shows that they are already showing some entrepreneurial intention by taking the course, but on the other hand, this also does not make them entrepreneurs. Therefore, we encourage further research to compare our results with non-entrepreneurship students or individuals who already founded a business to account for the generalization of our results.

Furthermore, we applied the TPB to investigate IEI in the IE context. Further studies could check if our results remain stable when using alternative theoretical frameworks to investigate entrepreneurial intentions, such as Shapero's Model [100]. Finally, to provide a more differentiated view on the relationship between digital capabilities and IE, further studies could assess more types of digital capabilities (like, for example, digital capabilities of employees or technical IT capabilities) and other IE outcomes like, for example, scope and speed of internationalization. 
Author Contributions: Conceptualization, L.v.A.; Data curation, L.v.A.; M.M.; Formal analysis, L.v.A.; Methodology, L.v.A.; M.M.; Writing-original draft, L.v.A. and M.M. All authors have read and agreed to the published version of the manuscript.

Funding: We acknowledge support by the German Research Foundation and the Open Access Publication Fund of TU Berlin.

Acknowledgments: We would like to thank Jan Kratzer for his overall support on our research project.

Conflicts of Interest: The authors declare no conflict of interest.

\section{Appendix A}

Table A1. Questionnaire variables: items, Cronbach's alpha, and references.

\begin{tabular}{|c|c|}
\hline Variables, Items and Cronbach's Alpha & Reference \\
\hline $\begin{array}{l}\text { IEI ( } 3 \text { items, } \alpha=0.91) \\
\text { Scale: Strongly disagree }(=1) \text { /Strongly agree }(=6) \\
\text { How well do the following statements describe you? } \\
\text { I plan to take steps to start an internationally operating business in the future. } \\
\text { I intend to take steps to start an internationally operating business in the future. } \\
\text { I will try to take steps to start an internationally operating business in the future. }\end{array}$ & $\begin{array}{c}\text { Adapted from (Kautonen, } \\
\text { van Gelderen, and Fink 2015) }\end{array}$ \\
\hline $\begin{array}{l}\text { Attitude towards IE }(6 \text { items, } \alpha=0.87) \\
\text { Scale: Strongly disagree }(=1) / \text { Strongly agree }(=6) \\
\text { Please rate the following statement based on the word pairs provided: "For me, } \\
\text { taking steps to start an internationally operating business would be ..." } \\
\ldots \text { unpleasant/attractive } \\
\ldots \text { useless/useful } \\
\ldots \text { foolish/wise } \\
\ldots \text { negative/positive } \\
\ldots \text { insignificant/important } \\
\ldots \text { tiresome/inspiring }\end{array}$ & $\begin{array}{c}\text { Adapted from Kautonen, } \\
\text { van Gelderen, and Fink (2015) }\end{array}$ \\
\hline
\end{tabular}

Subjective Norm (3 items, $\alpha=0.89$ )

Scale: Strongly disagree $(=1)$ /Strongly agree $(=6)$

How well do the following statements describe your situation?

My closest family members think that I should take steps to start an internationally

Adapted from Kautonen,
van Gelderen, and Fink (2015) operating business in the future.

My best friends think that I should take steps to start an internationally operating

business in the future.

PBC (4 items, $\alpha=0.70)$

Scale: Strongly disagree $(=1)$ /Strongly agree $(=6)$

Please indicate your opinion on the following statements.

If I wanted to, I could take steps to start an internationally operating business in the future.

If I took steps to start an internationally operating business in the future, I would be able to control the progress of the process to a great degree myself.

It would be easy for me to take steps to start an internationally operating business in the future.

If I wanted to take steps to start an internationally operating business in the future, no external factor, independent of myself, would hinder me in taking such action.

Stimulus Applied for Individual Digital Capabilities:

You are the founder of a startup which you would like to internationalize. As you have limited financial and personal resources, you are relying on your network and their knowledge to enter a foreign market. Your network looks like as followed:

You have your individual network with your family, friends and co-founder/employees who are going to help you with their individual knowledge and for example business contacts they have in the foreign market.

You also have a business network with other startups, business angels, local suppliers and customers.

Additionally, you also have a big institutional network based on supporting organizations like the Center for Entrepreneurship, Government agencies and business incubators. You are satisfied with the support you get from your network.

Then you are told about a new software to support your market entry. You have never worked with that software before.

Adapted from Kautonen, van Gelderen, and Fink (2015)
Stimulus adapted from Mullins and Sabherwal (2014) 
Table A1. Cont.

\begin{tabular}{|c|c|}
\hline Variables, Items and Cronbach's Alpha & Reference \\
\hline $\begin{array}{l}\text { Digital Capabilities ( } 9 \text { items, } \alpha=0.90) \\
\text { Scale: Very low extent }(=1) \text { /Very high extent }(=6) \\
\text { Please mark the extent to which you would rely on the new software. } \\
\text { To which extent would you rely on the new software to access information about } \\
\text { foreign markets and customer needs? } \\
\text { To which extent would you rely on the new software to enable strategic planning (for } \\
\text { example, market entry strategy, resources needed)? } \\
\text { To which extent would you rely on the new software to enable cost savings? } \\
\text { To which extent would you rely on the new software to enable competence/skills } \\
\text { development for international engagement? } \\
\text { To which extent would you rely on the new software to collaborate with business } \\
\text { partners (for example, suppliers)? } \\
\text { To which extent would you rely on the new software to enable work flexibility (for } \\
\text { example, work outside the office)? } \\
\text { To which extent would you rely on the new software to handle communication } \\
\text { within the business (with co-founder, employees)? } \\
\text { To which extent would you rely on the new software to handle external } \\
\text { communication with the business stakeholder? } \\
\text { To which extent would you rely on the new software to promote your product } \\
\text { and service? }\end{array}$ & $\begin{array}{l}\text { Adapted from Parida and Örtqvist } \\
\text { (2015)One item was excluded for } \\
\text { context reasons }\end{array}$ \\
\hline
\end{tabular}

\section{References}

1. von Briel, F.; Davidsson, P.; Recker, J. Digital Technologies as External Enablers of New Venture Creation in the IT Hardware Sector. Entrep. Theory Pract. 2018, 42, 47-69. [CrossRef]

2. Schiavone, F.; Tutore, I.; Cucari, N. How digital user innovators become entrepreneurs: A sociomaterial analysis. Technol. Anal. Strateg. Manag. 2020, 32, 683-696. [CrossRef]

3. Grant, R.M. Toward a knowledge-based theory of the firm. Strateg. Manag. J. 1996, 17, 109-122. [CrossRef]

4. Cragg, T.; McNamara, T. An ICT-based framework to improve global supply chain integration for final assembly SMES. J. Enterp. Inf. Manag. 2018, 31, 634-657. [CrossRef]

5. Aldrich, H.E. The Democratization of Entrepreneurship? Hackers, Makerspaces, and Crowdfunding. 2014. Available online: https://www.researchgate.net/profile/Howard_Aldrich/publication/ 268520673_The_Democratization_of_Entrepreneurship_Hackers_Makerspaces_and_Crowdfunding/ links/546f54730cf216f8cfa9d6c3/The-Democratization-of-Entrepreneurship-Hackers-Makerspaces-andCrowdfunding.pdf (accessed on 16 April 2019).

6. Deng, Z.; Wang, Z. Early-mover advantages at cross-border business-to-business e-commerce portals. J. Bus. Res. 2016, 69, 6002-6011. [CrossRef]

7. Oppong, G.Y.S.; Singh, S.; Kujur, F. Potential of digital technologies in academic entrepreneurship-a study. Int. J. Entrep. Behav. Res. 2020, in press. [CrossRef]

8. Rippa, P.; Secundo, G. Digital academic entrepreneurship: The potential of digital technologies on academic entrepreneurship. Technol. Forecast. Soc. Chang. 2019, 146, 900-911. [CrossRef]

9. Pergelova, A.; Manolova, T.; Simeonova-Ganeva, R.; Yordanova, D. Democratizing Entrepreneurship? Digital Technologies and the Internationalization of Female-Led SMEs. J. Small Bus. Manag. 2019, 57, 14-39. [CrossRef]

10. Loane, $\mathrm{S}$. The role of the internet in the internationalisation of small and medium sized companies. J. Int. Entrepr. 2005, 3, 263-277. [CrossRef]

11. Hagsten, E.; Kotnik, P. ICT as facilitator of internationalisation in small-and medium-sized firms. Small Bus. Econ. 2017, 48, 431-446. [CrossRef]

12. Reuber, A.R.; Fischer, E. International entrepreneurship in internet-enabled markets. J. Bus. Ventur. 2011, 26, 660-679. [CrossRef]

13. Brouthers, K.D.; Geisser, K.D.; Rothlauf, F. Explaining the internationalization of ibusiness firms. J. Int. Bus. Stud. 2016, 47, 513-534. [CrossRef]

14. Cavusgil, S.T.; Knight, G. The born global firm: An entrepreneurial and capabilities perspective on early and rapid internationalization. J. Int. Bus. Stud. 2015, 46, 3-16. [CrossRef]

15. Oviatt, B.M.; McDougall, P.P. Toward a Theory of International New Ventures. J. Int. Bus. Stud. 1994, 25, 45-64. [CrossRef] 
16. Knight, G.A.; Liesch, P.W. Internationalization: From incremental to born global. J. World Bus. 2016, 51, 93-102. [CrossRef]

17. Masiello, B.; Izzo, F. Interpersonal Social Networks and Internationalization of Traditional SMEs. J. Small Bus. Manag. 2019, 27, 17. [CrossRef]

18. Baron, R.A. Cognitive Mechanisms in Entrepreneurship: Why and When Entrepreneurs Think Differently Than Other People. J. Bus. Ventur. 1998, 13, 275-294.

19. Baron, R.A. Behavioral and cognitive factors in entrepreneurship: Entrepreneurs as the active element in new venture creation. Strat. Entrep. J. 2007, 1, 167-182. [CrossRef]

20. Harms, R.; Hatak, I.; Chang, M. Sensory processing sensitivity and entrepreneurial intention: The strength of a weak trait. J. Bus. Ventur. Insights 2019, 12, e00132. [CrossRef]

21. Glavas, C.; Mathews, S. How international entrepreneurship characteristics influence Internet capabilities for the international business processes of the firm. Int. Bus. Rev. 2014, 23, 228-245. [CrossRef]

22. Middermann, L.H. Do Immigrant Entrepreneurs Have Natural Cognitive Advantages for International Entrepreneurial Activity? Sustainability 2020, 12, 2791. [CrossRef]

23. Muzychenko, O.; Liesch, P.W. International opportunity identification in the internationalisation of the firm. J. World Bus. 2015, 50, 704-717. [CrossRef]

24. Ellis, P.D. Social ties and international entrepreneurship: Opportunities and constraints affecting firm internationalization. J. Int. Bus. Stud. 2011, 42, 99-127. [CrossRef]

25. Sommer, L.; Haug, M. Intention as a cognitive antecedent to international entrepreneurship —Understanding the moderating roles of knowledge and experience. Int. Entrep. Manag. J. 2011, 7, 111-142. [CrossRef]

26. Garrison, G.; Wakefield, R.L.; Kim, S. The effects of IT capabilities and delivery model on cloud computing success and firm performance for cloud supported processes and operations. Int. J. Inf. Manag. 2015, 35, 377-393. [CrossRef]

27. Nambisan, S. Digital Entrepreneurship: Toward a Digital Technology Perspective of Entrepreneurship. Entrep. Theory Pract. 2017, 41, 1029-1055. [CrossRef]

28. Bell, J.; Loane, S. 'New-wave' global firms: Web 2.0 and SME internationalisation. J. Mark. Manag. 2010, 26, 213-229. [CrossRef]

29. Etemad, H.; Wilkinson, I.; Dana, L.P. Internetization as the necessary condition for internationalization in the newly emerging economy. J. Int. Entrep. 2010, 8, 319-342. [CrossRef]

30. Glavas, C.; Mathews, S.; Bianchi, C. International opportunity recognition as a critical component for leveraging Internet capabilities and international market performance. J. Int. Entrep. 2017, 15, 1-35. [CrossRef]

31. Ajzen, I. The Theory of Planned Behavior. Organ. Behav. Hum. Decis. Process. 1991, 50, 179-211. [CrossRef]

32. Ajzen, I.; Madden, T.J. Prediction of Goal-Directed Behavior: Attitudes, Intentions, and Perceived Behavioral Control. J. Exp. Soc. Psychol. 1986, 22, 453-474. [CrossRef]

33. Ajzen, I. From Intentions to Actions: A Theory of Planned Behaviour; Springer: Berlin/Heidelberg, Germany, 1985; ISBN 978-3-642-69746-3.

34. Bandura, A. Self-Efficacy Mechanism in Human Agency. Am. Psychol. 1982, 37, 122-147. [CrossRef]

35. Ajzen, I. Perceived Behavioral Control, Self-Efficacy, Locus of Control, and the Theory of Planned Behavior. J. Appl. Soc. Psychol. 2002, 32, 665-683. [CrossRef]

36. Kautonen, T.; van Gelderen, M.; Fink, M. Robustness of the Theory of Planned Behavior in Predicting Entrepreneurial Intentions and Actions. Entrep. Theory Pract. 2015, 39, 655-674. [CrossRef]

37. Potishuk, V.; Kratzer, J. Factors Affecting Entrepreneurial Intentions and Entrepreneurial Attitudes in Higher Education. J. Entrep. Educ. 2017, 20, 25-44.

38. Jie, S.; Harms, R. Cross-Cultural Competences and International Entrepreneurial Intention: A Study on Entrepreneurship Education. Educ. Res. Int. 2017, 2017, 1-12. [CrossRef]

39. Sommer, L. Internationalization processes of small- and medium-sized enterprises-A matter of attitude? J. Int. Entrep. 2010, 8, 288-317. [CrossRef]

40. Stucki, T. How the founders' general and specific human capital drives export activities of start-ups. Res. Policy 2016, 45, 1014-1030. [CrossRef]

41. Jones, M.V.; Coviello, N.; Tang, Y.K. International Entrepreneurship research (1989-2009): A domain ontology and thematic analysis. J. Bus. Ventur. 2011, 26, 632-659. [CrossRef] 
42. Shane, S.A. A General Theory of Entrepreneurship. The Individual-Opportunity Nexus; Reprinted; Elgar: Cheltenham, UK, 2007; ISBN 9781843769965.

43. Zahra, S.A.; Korri, J.S.; Yu, J. Cognition and international entrepreneurship: Implications for research on international opportunity recognition and exploitation. Int. Bus. Rev. 2005, 14, 129-146. [CrossRef]

44. Covin, J.G.; Miller, D. International Entrepreneurial Orientation: Conceptual Considerations, Research Themes, Measurement Issues, and Future Research Directions. Entrep. Theory Pract. 2014, 38, 11-44. [CrossRef]

45. Kyvik, O. The global mindset: A must for international innovation and entrepreneurship. Int. Entrep. Manag. J. 2018, 14, 309-327. [CrossRef]

46. Felício, J.A.; Meidute, I.; Kyvik, Ø. Global mindset, cultural context, and the internationalization of SMEs. J. Bus. Res. 2016, 69, 4924-4932. [CrossRef]

47. Nummela, N.; Saarenketo, S.; Puumalainen, K. A Global Mindset-A Prerequisite for Successful Internationalization? Can. J. Adm. Sci. Rev. Can. des Sci. de L'Adm. 2004, 21, 51-64. [CrossRef]

48. Acedo, F.J.; Jones, M.V. Speed of internationalization and entrepreneurial cognition: Insights and a comparison between international new ventures, exporters and domestic firms. J. World Bus. 2007, 42, 236-252. [CrossRef]

49. Mohd Salleh, N.A.; Rohde, F.; Green, P. Information Systems Enacted Capabilities and Their Effects on SMEs' Information Systems Adoption Behavior. J. Small Bus. Manag. 2017, 55, 332-364. [CrossRef]

50. Bellini, C.G.P.; Isoni Filho, M.M.; de Moura Junior, P.J.; Pereira, R.d.C.d.F. Self-efficacy and anxiety of digital natives in face of compulsory computer-mediated tasks: A study about digital capabilities and limitations. Comput. Hum. Behav. 2016, 59, 49-57. [CrossRef]

51. Parida, V.; Örtqvist, D. Interactive Effects of Network Capability, ICT Capability, and Financial Slack on Technology-Based Small Firm Innovation Performance. J. Small Bus. Manag. 2015, 53, 278-298. [CrossRef]

52. Mathews, S.; Healy, M.; Wickramasekera, R. The Internetalisation of information, knowledge, and interaction components of the firm's internationalisation process. J. Mark. Manag. 2012, 28, 733-754. [CrossRef]

53. Ross, P.K.; Blumenstein, M. Cloud computing as a facilitator of SME entrepreneurship. Technol. Anal. Strateg. Manag. 2015, 27, 87-101. [CrossRef]

54. Jean, R.-J.; Sinkovics, R.R.; Cavusgil, S.T. Enhancing international customer-supplier relationships through IT resources: A study of Taiwanese electronics suppliers. J. Int. Bus. Stud. 2010, 41, 1218-1239. [CrossRef]

55. Tseng, K.-M.K.; Johnsen, R.E. Internationalisation and the internet in UK manufacturing SMEs. J. Small Bus. Enter. Dev. 2011, 18, 571-593. [CrossRef]

56. Bianchi, C.; Mathews, S. Internet marketing and export market growth in Chile. J. Bus. Res. 2016, 69, 426-434. [CrossRef]

57. Polo Peña, A.I.; Frías Jamilena, D.M.; Rodríguez Molina, M.Á. Impact of Market Orientation and ICT on the Performance of Rural Smaller Service Enterprises. J. Small Bus. Manag. 2011, 49, 331-360. [CrossRef]

58. Chandra, Y.; Coviello, N. Broadening the concept of international entrepreneurship: 'Consumers as International Entrepreneurs'. J. World Bus. 2010, 45, 228-236. [CrossRef]

59. Kolvereid, L. Prediction of Employment Status Choice Intentions. Entrep. Theory Pract. 1996, 21, 47-58. [CrossRef]

60. Oviatt, B.M.; McDougall, P.P. Defining International Entrepreneurship and Modeling the Speed of Internationalization. Entrep. Theory Pract. 2005, 29, 537-554. [CrossRef]

61. Keh, H.T.; Foo, M.D.; Lim, B.C. Opportunity Evaluation under Risky Conditions: The Cognitive Processes of Entrepreneurs. Entrep. Theory Pract. 2002, 27, 125-148. [CrossRef]

62. Forlani, D.; Mullins, J.W. Perceived risks and choices in entrepreneurs' new venture decisions. J. Bus. Ventur. 2000, 14, 305-322. [CrossRef]

63. Mathews, S.; Healy, M. The internet and information capability reduces perceived risk of internationalisation: An Australian SME perspective. Int. J. Organ. Behav. 2007, 12, 71-87.

64. Cialdini, R.B. The Focus Theory of Normative Conduct. In Theories of Social Psychology; Kruglanski, A.W., Higgins, E.T., van Lange, P.A.M., Eds.; Sage: Los Angeles, CA, USA, 2012; pp. 295-312. ISBN 9780857029614.

65. Ajzen, I.; Fishbein, M. Understanding Attitudes and Predicting Social Behavior; Prentice-Hall: Englewood Cliffs/London, UK, 1980; ISBN 0139364439.

66. Fisher, J.D.; Fisher, W.A.; Amico, K.R.; Harman, J.J. An information-motivation-behavioral skills model of adherence to antiretroviral therapy. Health Psychol. 2006, 25, 462-473. [CrossRef] [PubMed] 
67. Carr, J.C.; Sequeira, J.M. Prior family business exposure as intergenerational influence and entrepreneurial intent: A Theory of Planned Behavior approach. J. Bus. Res. 2007, 60, 1090-1098. [CrossRef]

68. Zapkau, F.B.; Schwens, C.; Steinmetz, H.; Kabst, R. Disentangling the effect of prior entrepreneurial exposure on entrepreneurial intention. J. Bus. Res. 2015, 68, 639-653. [CrossRef]

69. Miniard, P.W.; Cohen, J.B. Modeling Personal and Normative Influences on Behavior. J. Consum. Res. 1983, 10, 169. [CrossRef]

70. Middermann, L.H.; Kratzer, J.; Perner, S. The Impact of Environmental Risk Exposure on the Determinants of Sustainable Entrepreneurship. Sustainability 2020, 12, 1534. [CrossRef]

71. Neubert, M. The Impact of Digitalization on the Speed of Internationalization of Lean Global Startups. TIM Rev. 2018, 8, 44-54. [CrossRef]

72. Mathews, S.; Bianchi, C.; Perks, K.J.; Healy, M.; Wickramasekera, R. Internet marketing capabilities and international market growth. Int. Bus. Rev. 2016, 25, 820-830. [CrossRef]

73. Alderete, M.V. Mobile Broadband: A Key Enabling Technology for Entrepreneurship? J. Small Bus. Manag. 2017, 55, 254-269. [CrossRef]

74. Esfandiar, K.; Sharifi-Tehrani, M.; Pratt, S.; Altinay, L. Understanding entrepreneurial intentions: A developed integrated structural model approach. J. Bus. Res. 2019, 94, 172-182. [CrossRef]

75. Fitzsimmons, J.R.; Douglas, E. Interaction Between Feasibility and Desirability in the Formation of Entrepreneurial Intentions. J. Bus. Ventur. 2011, 26, 431-440. [CrossRef]

76. Kuckertz, A.; Wagner, M. The influence of sustainability orientation on entrepreneurial intentions-Investigating the role of business experience. J. Bus. Ventur. 2010, 25, 524-539. [CrossRef]

77. Liñán, F.; Chen, Y.-W. Development and Cross-Cultural Application of a Specific Instrument to Measure Entrepreneurial Intentions. Entrep. Theory Pract. 2009, 33, 593-617. [CrossRef]

78. Zellweger, T.; Sieger, P.; Halter, F. Should I stay or should I go? Career choice intentions of students with family business background. J. Bus. Ventur. 2011, 26, 521-536. [CrossRef]

79. Saeed, S.; Yousafzai, S.Y.; Yani-De-Soriano, M.; Muffatto, M. The Role of Perceived University Support in the Formation of Students' Entrepreneurial Intention. J. Small Bus. Manag. 2015, 53, 1127-1145. [CrossRef]

80. Karimi, S.; Biemans, H.J.A.; Lans, T.; Chizari, M.; Mulder, M. The Impact of Entrepreneurship Education: A Study of Iranian Students' Entrepreneurial Intentions and Opportunity Identification. J. Small Bus. Manag. 2016, 54, 187-209. [CrossRef]

81. Maresch, D.; Harms, R.; Kailer, N.; Wimmer-Wurm, B. The impact of entrepreneurship education on the entrepreneurial intention of students in science and engineering versus business studies university programs. Technol. Forecast. Soc. Chang. 2016, 104, 172-179. [CrossRef]

82. Pérez-Macías, N.; Fernández-Fernández, J.-L.; Rúa Vieites, A. The impact of network ties, shared languages and shared visions on entrepreneurial intentions of online university students. Available online: https: //repositorio.comillas.edu/xmlui/handle/11531/36609 (accessed on 25 September 2020).

83. Al-Jubari, I. College Students' Entrepreneurial Intention: Testing an Integrated Model of SDT and TPB. SAGE Open 2019, 9, 215824401985346. [CrossRef]

84. Fayolle, A.; Liñán, F. The future of research on entrepreneurial intentions. J. Bus. Res. 2014, 67, $663-666$. [CrossRef]

85. Mullins, J.; Sabherwal, R. How Much Information is Too Much? Effects of Computer Anxiety and Self-Efficacy. Available online: https:/www.semanticscholar.org/paper/How-Much-Information-is-Too-Much-Effects-ofAnxiety-Mullins-Sabherwal/f7ba343eaa494db1661de459c78c471fc408db56 (accessed on 25 September 2020).

86. Field, A. Discovering Statistics Using SPSS, 3rd ed.; Sage publications: Los Angeles, CA, USA, 2009.

87. Midi, H.; Sarkar, S.K.; Rana, S. Collinearity diagnostics of binary logistic regression model. J. Interdiscip. Math. 2010, 13, 253-267. [CrossRef]

88. Grewal, R.; Cote, J.A.; Baumgartner, H. Multicollinearity and Measurement Error in Structural Equation Models: Implications for Theory Testing. Mark. Sci. 2004, 23, 519-529. [CrossRef]

89. MacKinnon, D.P.; Lockwood, C.M.; Hoffmann, J.M.; West, S.G.; Sheets, V. A Comparison of Methods to Test Mediation and Other Intervening Variable Effects. Psychol. Methods 2002, 7, 83-104. [CrossRef] [PubMed]

90. Zhao, X.; Lynch, J.G.; Chen, Q. Reconsidering Baron and Kenny: Myths and Truths about Mediation Analysis. J. Consum. Res. 2010, 37, 197-206. [CrossRef]

91. Baron, R.M.; Kenny, D.A. The Moderator-Mediator Variable Distinction in Social Psychological Research: Conceptual, Strategic, and Statistical Considerations. J. Personal. Soc. Psychol. 1986, 51, 1173-1182. [CrossRef] 
92. Preacher, K.J.; Hayes, A.F. SPSS and SAS procedures for estimating indirect effects in simple mediation models. Behav. Res. Methods Instrum. Comput. 2004, 36, 717-731. [CrossRef] [PubMed]

93. Williams, L.J.; Vandenberg, R.J.; Edwards, J.R. 12 Structural Equation Modeling in Manag. Research: A Guide for Improved Analysis. ANNALS 2009, 3, 543-604. [CrossRef]

94. Podsakoff, P.M.; MacKenzie, S.B.; Lee, J.-Y.; Podsakoff, N.P. Common method biases in behavioral research: A critical review of the literature and recommended remedies. J. Appl. Psychol. 2003, 88, 879-903. [CrossRef]

95. Iacobucci, D. Structural equations modeling: Fit Indices, sample size, and advanced topics. J. Consum. Psychol. 2010, 20, 90-98. [CrossRef]

96. Hu, L.-t.; Bentler, P.M. Cutoff criteria for fit indexes in covariance structure analysis: Conventional criteria versus new alternatives. Struct. Equ. Modeling: A Multidiscip. J. 1999, 6, 1-55. [CrossRef]

97. Middermann, L.H.; Rashid, L. Cross-Country Differences in Entrepreneurial Internationalization Tendencies: Evidence from Germany and Pakistan. Adm. Sci. 2019, 9, 54. [CrossRef]

98. Sinkovics, N.; Sinkovics, R.R.; Jean, R.-J. The internet as an alternative path to internationalization? Int. Mark. Rev. 2013, 30, 130-155. [CrossRef]

99. Davidsson, P.; Honig, B. The role of social and human capital among nascent entrepreneurs. J. Bus. Ventur. 2003, 18, 301-331. [CrossRef]

100. Schlaegel, C.; Koenig, M. Determinants of Entrepreneurial Intent: A Meta-Analytic Test and Integration of Competing Models. Entrep. Theory Pract. 2014, 38, 291-332. [CrossRef]

(C) 2020 by the authors. Licensee MDPI, Basel, Switzerland. This article is an open access article distributed under the terms and conditions of the Creative Commons Attribution (CC BY) license (http://creativecommons.org/licenses/by/4.0/). 